\title{
Characterization of Beekeeping System in Horo District, Horo Guduru Wollega Zone, Oromia Regional State, Ethiopia
}

\author{
Alemayehu Tolera ${ }^{1, *}$, Desalegn Begna ${ }^{2}$, Simret Betsha ${ }^{1}$ \\ ${ }^{1}$ Department of Animal and Range Sciences, School of Animal and Range Sciences, Hawassa College of Agriculture, Hawaasa, \\ Ethiopia. \\ ${ }^{2}$ Ethiopian Policy study Institute, Addis Ababa, Ethiopia.
}

\begin{abstract}
How to cite this paper: Alemayehu Tolera, Desalegn Begna, Simret Betsha. (2022) Characterization of Beekeeping System in Horo District, Horo Guduru Wollega Zone, Oromia Regional State, Ethiopia. International Journal of Food Science and Agriculture, 6(1), 44-59.

DOI: $10.26855 /$ ijfsa.2022.03.007

Received: December 24, 2021

Accepted: January 22, 2022

Published: February 18, 2022

*Corresponding author: Alemayehu Tolera, Department of Animal and Range Sciences, School of Animal and Range Sciences, Hawassa College of Agriculture, Hawaasa, Ethiopia. Email: toleraalex@gmail.com
\end{abstract}

\begin{abstract}
The study was conducted in Horo districts of Horo Guduru Wollega Zone, Oromia Regional state, western Ethiopia to assess beekeeping practices. The peasant associations of the districts were stratified into highland and midland. From each agro-ecology, three peasant associations (PA's) were selected purposively based on beekeeping potentials and accessibility. Furthermore from each PA's 30 beekeepers and a total of 180 beekeepers were selected using purposive sampling method. The selected beekeepers were interviewed using pre-tested structured questioners and single-visit-multiple formal survey method to collect the data. Data were analysed using SPSS version 20 software. The survey result indicated that $66.3 \%$ of the beekeepers started beekeeping by catching bee swarms freely, while the remaining $17.6 \% 14.4 \%$ and $1.7 \%$ getting bee colonies through gift from parents and both catching bee swarm and gift from parents and through inheritance respectively. The data revealed that majority about (96.2\%) of the respondents follow traditional production system. An average honeybee colony holding size per household head of the study area was about 9.58, 2.18 and 2.62 with mean honey yields of $5.14 \mathrm{~kg}, 15 \mathrm{~kg}$ and $22.54 \mathrm{~kg}$ from traditional, transitional and modern beehives respectively. However, as the study result indicated $68.5 \%$ respondents replied that decreasing trends in the number of honeybee colony and the honey yields due to pesticide and herbicide application (22.\%), Pests (16.6\%), absconding (15.5\%) and Migration (12.7\%). The behaviors of the bees were docile (27.1\%), aggressive (49.7\%), and very aggressive (23.2\%). As the result indicated that indiscriminate use of agro-chemicals (31.4\%), honeybee enemies (21\%), lack of bee forages (19.3\%), lack of protection against bad weather (16\%) and poor management of beekeeping (13.3\%) were reason of honeybee absconding in the study area. About $99.5 \%$ beekeepers responded that the incidences of reproductive swarming of honeybee colony in their apiary while the remaining $0.5 \%$ had no awareness about swarming. The current study showed that the beekeepers inspect their hive externally (87.8\%), internally (9.4\%) and not inspect their honeybee colony (2.8\%). The common smoking materials in the study area was Ekebergia capensi (somboo) (49.4\%), Olea europaea (ejersa) (22.2\%), cow dung (dike) (16.7\%), Karabicho (6.10\%), Beeswax (gaga) (5\%) and Gari (0.6\%). In general, the present study showed that the area is very potential for beekeeping and majority of the households keep honeybees. Thus, strong extension, technical intervention and technology adoption is important to improve the beekeeping system of the area so that it can meaningfully contribute to the livelihood of small holder large beekeepers in Horo district.
\end{abstract}




\section{Keywords}

Beekeeping, Honeybee, Swarming, Absconding, Horo

\section{Introduction}

In Ethiopia, beekeeping is one of the important agricultural activities most broadly spread making substantial contribution to household food security. It provides income, quality foods and assets to the rural beekeepers [1]. Owing to its tremendous agro-climatic conditions and biodiversity, the country is home to most diverse flora and fauna [2] and [3]. This makes the country highly suitable for sustaining a large number of bee colonies [4]. According to [5], about $6,523,969$ million bee colonies are estimated to be managed in the rural sedentary areas of the country. From these total beehives, 3,185,361 beehives are from Oromia Region accounting about 49\% of the country's bee colony population. With this bee colony population, the country is one of the leading honey producers in Africa and third largest beeswax producer in the world [6]. An Ethiopian honey production accounts approximately $2.5 \%$ of world production and $21.7 \%$ of African honey production [6].

Owing to increase in income and human population, there is large growing demand for natural products like honey and other bee products worldwide for its high nutritional and/or medicinal values [7] and [8]. However, being the leading honey and beeswax producers, the contribution of the sub-sector to the agricultural GDP (1.3\%) [8] Which has never been corresponding with the huge numbers of honeybee colonies and the country's immense resources for beekeeping [9]. Furthermore, the beekeeping development of the country and its benefit are currently challenged by many and interrelated factors like ecological degradation, recurrent drought, farmland expansion, recently emerging bee pest and diseases, indiscriminate use of agro-chemicals, low technology input, poor pre and post-harvest management, inadequate extension services and poor marketing infrastructure [10] and [1]. Low productivity and quality of bee products are also among the major economic impediments for beekeepers [11].

Horo district is one of the districts of Horo Guduru Wollega zone of Oromia regional state. Like the other parts of the region, beekeeping is one of the traditional activities in the district practiced as side-line to other agriculture like crop production and animal husbandry. With its suitable agro-climatic conditions and biodiversity Horo district is highly suitable and very ideal place for beekeeping and hence, about $44 \%$ of the total households living in the district practices beekeeping [12]. However, the beekeeping and honey systems prevailing in Horo district is not characterized and documented. Therefore, this study aims to characterize and document the beekeeping and honey production systems of district.

\section{Materials and Methods}

\subsection{Description of the Study Area}

Horo district is one of the districts Horo Guduru Wollega zone of Oromia regional State, Ethiopia. The district is located at $340 \mathrm{~km}$ west of Addis Ababa with $9^{\circ} 34^{\prime} \mathrm{N}$ latitude and $37^{\circ} 06^{\prime} \mathrm{E}$ longitudes (Figure 1). The district consists 114,243 of human population of which 57,022 males and 57,221 females. The district is mainly characterized by two major agro-ecologies, namely; highland (49.8\%) and midland (48.9\%). Total land area of the district is 77,998 ha of which $71 \%$ of the area cultivated with crops, $8.3 \%$ used for pasture, $12 \%$ covered by forests, $6 \%$ swampy and the remaining 2.7\% unproductive or degraded [13]. Mixed crop-livestock agriculture is the main stay of the farming communities and maize, wheat, barley, Teff, field peas and faba beans, potatoes, other fruit and vegetables are the major grown crops. Livestock species raised in the district include cattle, sheep, horses, poultry, goats, donkey, mules and bee colonies. The district have only one long rainy season from March to mid-October with mean annual precipitation of about $1800 \mathrm{~mm}$ [12], mean temperatures of $22^{\circ} \mathrm{C}$ [13].

\subsection{Sampling Techniques and Sampling Size}

The study was community based cross-sectional survey based on the representativeness from the two agro-ecological zones with respect to honeybee colonies potential, 6 Kebeles administrations (Midland 3 and Highland 3) were selected using purposive sampling technique. Per Kebele administration 30 beekeepers a total of 180 respondents from the two agro-ecological zones were selected from based on owing bee colonies using random sampling method. The selected beekeepers were interviewed using structured questionnaires that was pre-tested and translated into Afan Oromo language. 


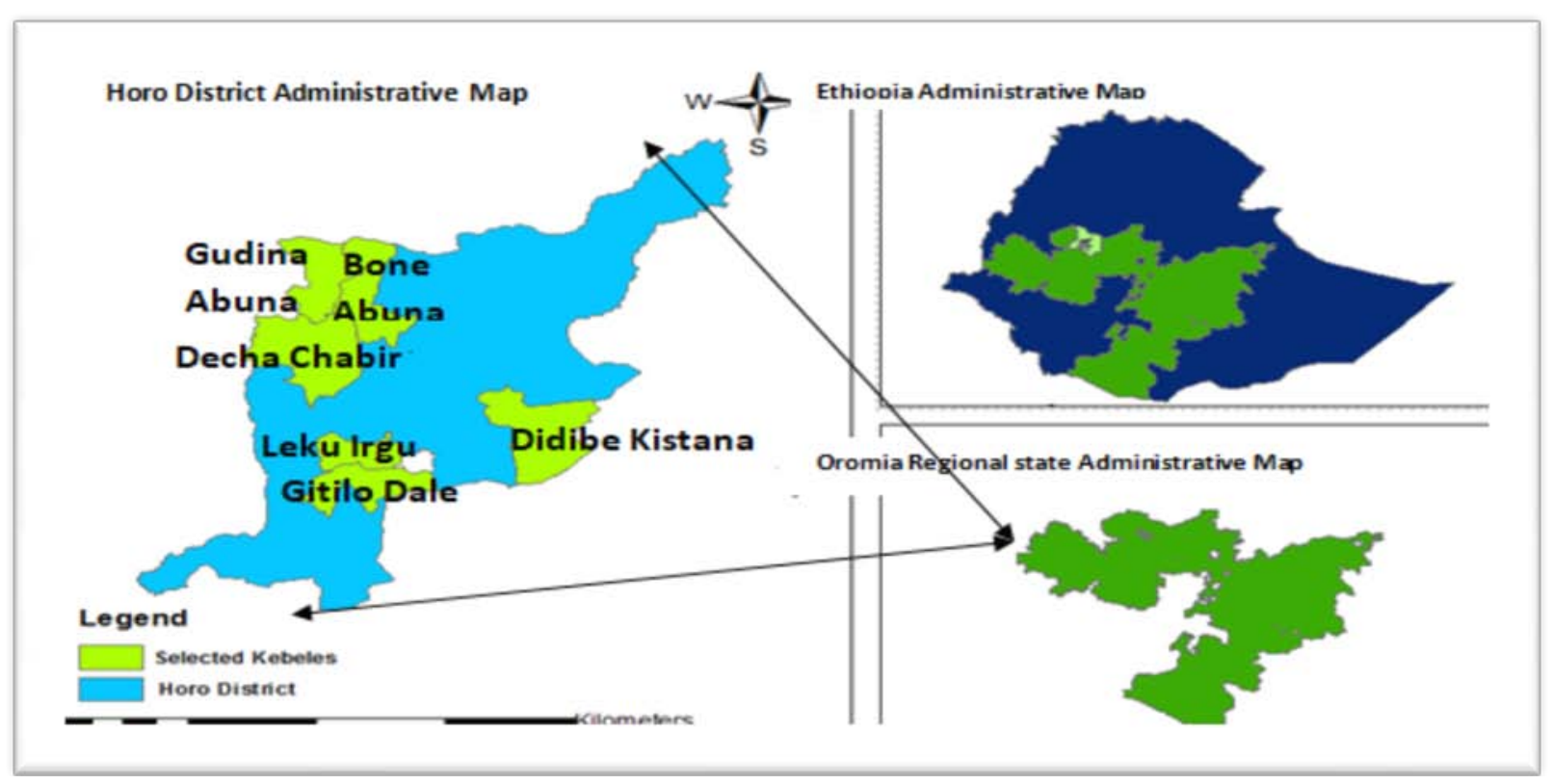

Figure 1. Location map of the study district.

\subsection{Methods of Data Collection and Data Sources}

Both primary and secondary data were collected to achieve the objectives of the study. Secondary data were obtained from reports of district Agricultural Development Office, Zonal Agricultural Development Office, NGOs and other published and unpublished materials. Whereas, the primary data was collected through household interview key informant interview and focus group discussions. The primary data collections were run through household interviewing sample respondents on structured questionnaire. Pre-testing of the questionnaire was made as a pilot survey and modification was made on the questionnaire was done on the basis of information obtained during pre-testing. Single-visit-multiple-subject formal survey method [14] was also a part of data collection on various aspects of beekeeping production and management practices. Enumerators were recruited and trained to collect the data under the supervision of the researcher. Key informant interview included district beekeeping expert, development agents (DAs) of the study area, farmer beekeepers and the focus group discussions included the purposively selected PA leaders, DAs and bee technicians, and some individuals who are believed to be knowledgeable on beekeeping.

\section{Results and Discussion}

\subsection{Socio-Economic Characteristics of Households}

\subsubsection{Sex of respondents}

From the total of 180 sample households interviewed, about $98.9 \%$ were male headed and the rest $1.1 \%$ were female headed households (Figure 2). The report shows that beekeeping activity is dominated by males and women are not allowed to involve in beekeeping activities in the study area. This study investigation is similar with the investigation at the various parts of the country illustrating that Ethiopia traditionally beekeeping is men's job in Sothern Ethiopia [15], beekeeping is male headed households dominated activity in Tigray [16] and beekeeping as men's dominating practice in Bale [17]. Consequently gender prohibition remains decline productivity, given the well-known fact that the woman contributes more than half to the household's food and cash crop production and questions that fact that beekeeping can be done by any sex.

\subsubsection{Age of respondents}

Survey result showed that the beekeepers household head age ranges from 20-81 years old with mean age of 46.12 (Table 1) of which more than $86 \%$ of the respondents are less than 50 years. The finding shows that the majority of the beekeepers are in their active and productive age group and there was no significant difference $(\mathrm{P}>0.05)$ in age between the studied peasant associations (PAs) (Figure 3). This result shows that beekeeping can be performed by all age groups and reasonably without any difficulties and more actively performed by younger age groups. Similarly [18] reported the most productive age are actively involved, accommodating experiences from elders and finally become independent beekeepers. 


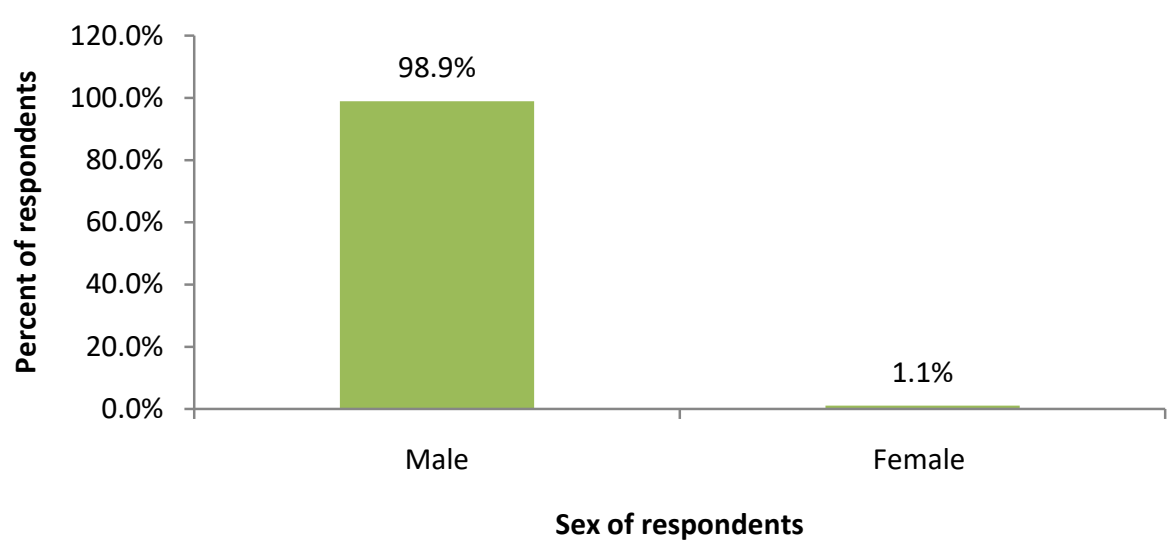

Figure 2. Sex of respondents in the study area.

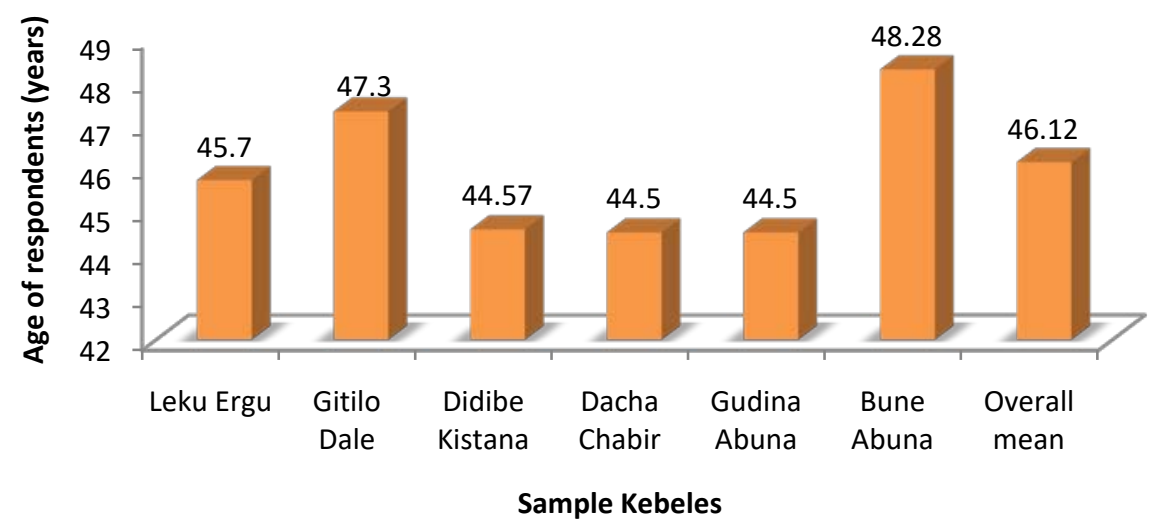

Figure 3. Mean age of respondents in the study area.

\subsubsection{Family size of the respondents}

The beekeepers that have different family size were engaged in beekeeping activity. The mean family size of the household beekeepers of the study area was 5.78 (Figure 4).

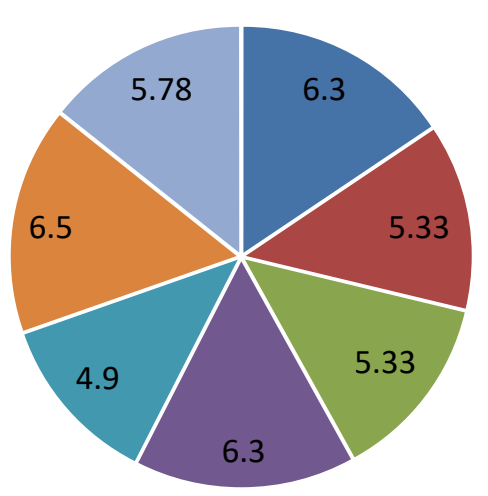

$$
\begin{aligned}
& \text { Leku Ergu } \\
& \text { Gitilo Dale } \\
& \text { Didibe Kistana } \\
& \text { Dacha Chabir } \\
& \text { Gudina Abuna } \\
& \text { Bune Abuna } \\
& \text { Overall mean }
\end{aligned}
$$

Figure 4. Mean family size of respondents in the study area.

\subsubsection{Education status of beekeepers}

The educational status of sampled respondents showed only $10 \%$ are illiterate and the remaining $50 \%, 34.4 \%$ and 
5.6\% are with elementary and junior school (grade 1-8), high school and preparatory school (grade 9-12) and middle level profession (level I-IV) attended, respectively (Figure 5). In the study area educational level has a significant effect on technology adoption and it may have great importance in identifying and determining the type of development and extension service approaches in order to improve the livelihoods of small holder beekeepers (farmers). As the study result indicated, those beekeepers with an education category of grades 9 and above were adopting improved beekeeping technology, holds high number of honeybee colonies and practices good honeybee management. Similar reports were noted by [19], [20] and [17]. It is also observed that education had significant effect on adoption of improved beekeeping technology, beekeeping experience and number of bee colony holdings between illiterate and literate beekeepers. Similarly as study result showed that those beekeepers with in education category of grades (9-12) and hold TVET education certificate in Level I-IV had more bee colony with frame and transitional beehives of produced quality bee products and involved in bee product marketing. It is observed that literate beekeepers holds more honeybee colonies with improved beekeeping technology, practices better honeybee management and more involved in honeybee product marketing than illiterate beekeepers.

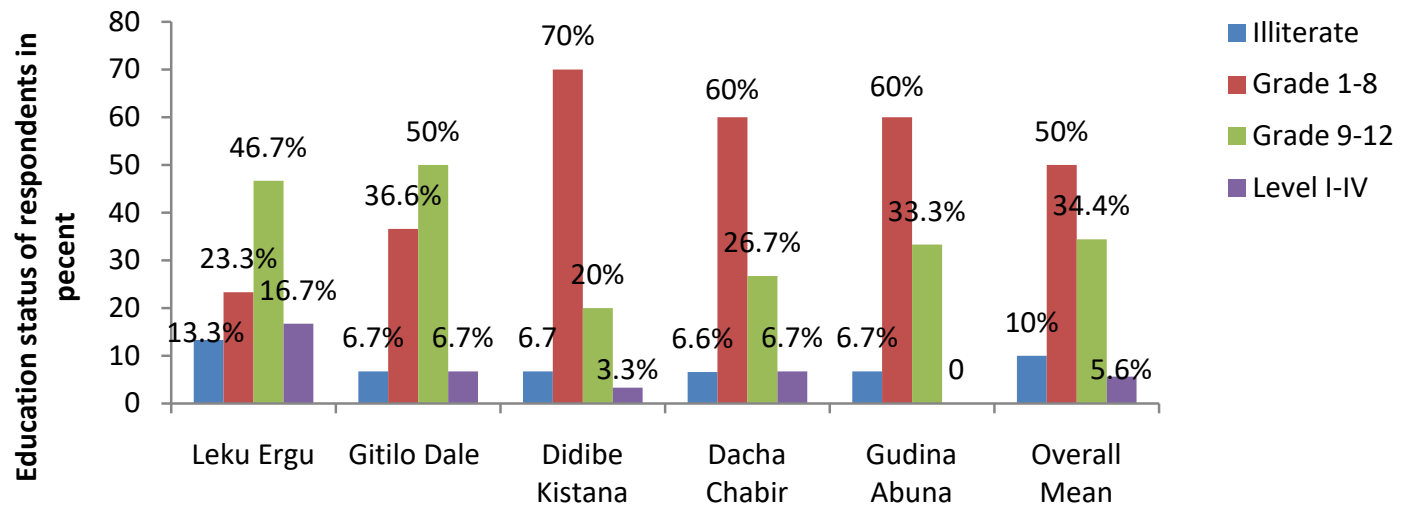

Sample kebeles of the study area

Figure 5. Education status of beekeepers in the study area.

\subsection{Major Beekeeping Activities}

\subsubsection{Sources of Honeybee Colonies and hive placement}

The study result indicated that $66.3 \%$ of the beekeepers started beekeeping by catching bee swarms, while the remaining $17.6 \% 14.4 \%$ and $1.7 \%$ getting bee colonies through gift from parents and both catching bee swarm and gift from parents and through inheritance respectively (Figure 6). In the study area, majority of the beekeepers was started beekeeping through catching bee swarms freely. This finding agree with [17], [21], and [18] reported that majority of beekeepers initiated beekeeping through swarm catching in Bale zone of Oromia Region, Burie district of Amhara region and Gomma district respectively. However, it also showed that there were no single respondent beekeepers that started beekeeping through buying honeybee colony as a result of honeybee colony selling is uncommon in the study area.

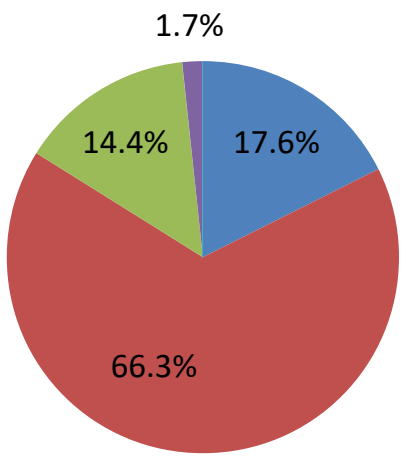

Gift from parents

- Catching bee swarm

Both catching and gift from parents

- Through inheritance

Figure 6. Sources of honeybee colonies in the study. 
As the study result indicated that household beekeepers place their traditional hive at backyard (2.3\%), under the eaves of the house (19.9\%), under the shelter (1.1\%), hanging on the trees near homestead (26.5\%), hanging on trees in the forest area (1.7\%), both under the eaves and hanging on trees near homestead (47.9\%) and hanging on the trees near homestead and in the forest area (0.6\%). However, about 49.84\%, 11.83\% and 58.33\% beekeepers place intermediate beehive at back yard, under the eaves house and under the shelter and about 42.6\%, 17.1\%, and 40.3\% place movable-frame hives at back yard, under the eaves house and under the shelter (Figure 7).

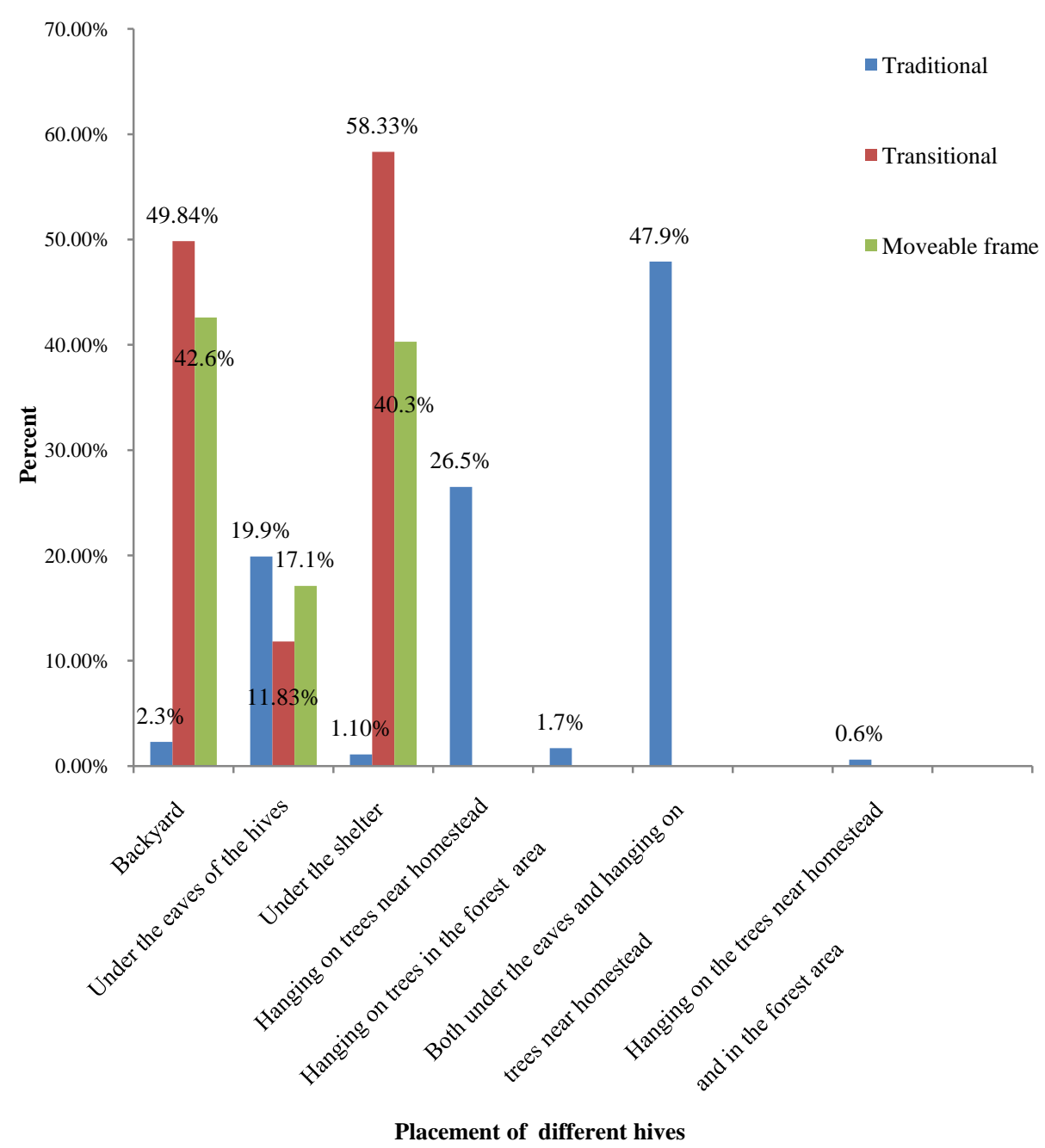

Figure 7. Placement of different beehives after getting colony.

\subsubsection{Honeybee colony holding and composition}

Regarding the honeybee colony holding in the study area, the result showed that the mean honeybee colony holdings in Dacha Chabir (10.49) and Bone Abuna (10.47) was significantly higher $(\mathrm{P}<0.05)$ than that of Leku Ergu (8.44), Gitilo Dale (8.41), Didibe Kistana (8.49) and Gudina Abuna (8.18). The high colony owning at Decha Chabir (10.49) and Bone Abuna (10.47) peasant associations might be due to the presence of abundant honeybee flora and favorable environment for beekeeping. However, no significant difference ( $\mathrm{P}>0.05$ ) was observed between Leku Ergu (8.44), Gitilo Dale (8.41), Didibe Kistana (8.49) and Gudina Abuna (8.18) peasant associations (Table 2). This might be the three kebeles have no abundant honeybee flora as Dacha Chabir and Bone Abuna kebeles. The overall mean of the study area was 9.08 honeybee colonies per household in traditional production system. This results agree with [21] and [17] reported that the mean honeybee's colony holding in traditional hive is 7.75 per household. 
Table 1. The average honeybee colony (three hives) per households in the study

\begin{tabular}{ccc}
\hline & Number of honeybees colony owning (N=180) & Mean \pm SE \\
\hline Kebeles & Range & $8.44 \pm 0.49^{\mathrm{b}}$ \\
Leku Ergu & $3-45$ & $8.41 \pm 1.02^{\mathrm{b}}$ \\
Gitilo Dale & $3-60$ & $10.49 \pm 1.26^{\mathrm{a}}$ \\
Dacha Chabir & $3-80$ & $8.49 \pm 1.26^{\mathrm{b}}$ \\
Didibe Kistana & $3-65$ & $8.18 \pm 1.41^{\mathrm{b}}$ \\
Gudina Abuna & $3-75$ & $10.74 \pm 1.13^{\mathrm{a}}$ \\
Bone Abuna & $3-91$ & $9.08 \pm 1.095$ \\
\hline
\end{tabular}

Different letter (ab) across the column indicate significant difference at $\mathrm{p}<0.05$ level, $\mathrm{SE}=$ Standard Error, $\mathrm{N}=$ number of respondents

Regarding the compositions of beehives types, as the study result showed that majority of the beekeepers, about $26.7 \%$ only use traditional hive. Whereas, about $1.7 \%$ and $0.6 \%$ of household beekeepers were use only transitional and moveable frame hive (Figure 8). This finding indicated that low adoption of improved beekeeping technology in the study area. This low adoption of improved hive technology might be due to high cost beekeeping equipment, difficult to construct, poor beekeeping extension services, lack of know how about improved beekeeping.

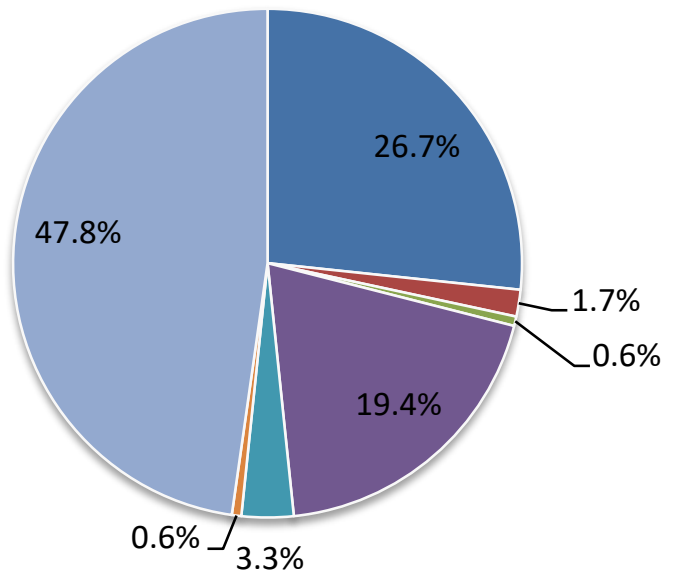

- Only Traditional hive

- Only Transitional hive

- Only moveable frame

- Traditional and Transitional

- Traditional and Moveable frame

- Transitional and moveable frames

- Traditional, transitional and Moveable frames

Figure 8. Distribution of bee hive types in the study area.

\subsection{Beekeeping practices and trends in Study Area}

\subsubsection{Beekeeping practices in study area}

Beekeeping is not new practice in Ethiopia in general and in Horo particular; it is an oldest farming activity which is practiced as a sideline with other farm activities. Yet in Horo, there are three types of beekeeping practices namely; traditional, transitional and movable-frame based on the types of beehives used.

\subsubsection{Traditional hives beekeeping practice}

As the survey result showed, there are two categories of traditional beehives which were commonly used in the study area. These include: Mud hive and Basket hive type, but two of them were oval in shape with the dimension of around $90 \mathrm{~cm}-1 \mathrm{~m}$ in length and a diameter of approximately $30 \mathrm{~cm}$. Based on the information gathered from beekeepers', the interior and exterior of the traditional hive were plastering by mud/cow dung and grass, straw and bamboo sheath respectively to protect bees from cold weather conditions, rain and sunlight.

According to the survey result, the mean bee colony owing of traditional hive beekeepers in Bone Abuna (10.70) and Dacha Chabir $(10.63)$ was significantly higher $(\mathrm{P}<0.05)$ than that of other peasant associations (Table 2). This significance difference might be due to the suitability of the environment (abundant honeybee flora) for beekeeping. But, there were no significant difference between Leku Ergu (8.96), Didibe Kistana (8.53), Gitilo Dale (8.86) and Gudina Abuna (9.8) (Table 2) in owning honeybee colonies with traditional beehives. The minimum and maximum of honeybee colony holding in traditional beehives were 4 to 80 per household. The overall mean of bee colony holding in traditional 
was 9.58 per household. This finding indicated that the mean honeybee colony holding per-household head in the study area was not more than ten beehives. Similarly, [15] and [17] reported that in average the high land of Ethiopia beekeepers normally do not possess more than 10 beehives.

Table 2. Average traditional hive per households in Horo district

\begin{tabular}{cccc}
\hline & $\begin{array}{c}\text { Number of traditional honeybees colony owning (N=180) } \\
\text { Kebeles }\end{array}$ & Minimum & Maximum \\
\hline Leku Ergu & 5 & 13 & $8.96 \pm 0.38^{\mathrm{b}}$ \\
Gitilo Dale & 5 & 12 & $8.86 \pm 0.33^{\mathrm{b}}$ \\
Dacha Chabir & 4 & 50 & $10.63 \pm 1.42^{\mathrm{a}}$ \\
Didibe Kistana & 5 & 13 & $8.53 \pm 0.47^{\mathrm{b}}$ \\
Gudina Abuna & 5 & 16 & $9.80 \pm 0.57^{\mathrm{b}}$ \\
Bone Abuna & 4 & 80 & $10.70 \pm 2.42^{\mathrm{a}}$ \\
Overall mean & 4 & 80 & $9.58_{ \pm}+0.93$
\end{tabular}

Different letter (ab) across the column indicate significant difference at $\mathrm{p}<0.05$ level, SE= Standard Error, $\mathrm{N}=$ number of respondents.

According to survey result, traditional beekeeping is placed in two forms, namely; near homestead and under the eaves of the house beekeeping. Near homestead beekeeping which is practiced in near home by hanging beehives on long trees (Cordial Africana, Eucalyptus camaldulensis and Podocarpus falcatus) and with no management care for honeybees and their products. This type of traditional beekeeping is the dominant honey production in the study area. However, beekeeping under the eaves of the house which is practiced around homestead with relatively better management provided to bee colonies (providing powder, syrup and water) as compared to near homestead beekeeping. According to information gathered from respondents, forest beekeeping is not common in the study area most likely due to predator and theft.

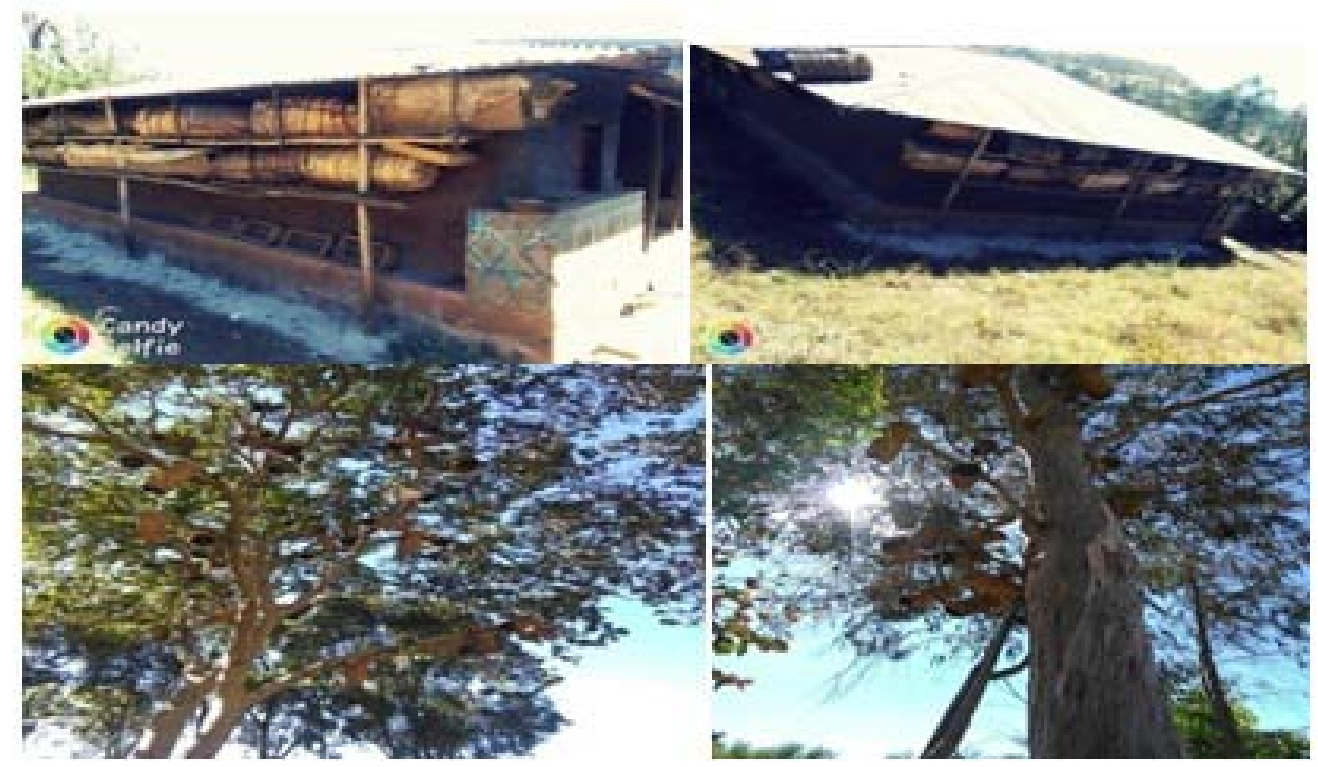

Figure 9. Traditional beekeeping under eaves of house on the top and on trees near homestead at bottom in Horo district.

\subsubsection{Transitional hives beekeeping practice}

It is one of the improved bee hive technology of beekeeping practiced in the study area. As the study result indicated that about $1.7 \%$ of household beekeepers use only transitional beehives (Figure 3). The distribution of transitional beehives in the study area was very limited and this probably due to poor beekeeping extension services and weak intervention by government and non-government organizations in the study area. The study result illustrated that the average transitional honeybee colony owned per household heads were 2.62 which is insignificant as compared to traditional hive beekeeping practice. However, currently efforts are made by NGOs (education for development association) (EFDA), Government Organizations namely; sustainable land management office and Agricultural Growth Program in 
providing training to model framers focused on practical demonstration that equip the beekeepers with skill and right attitude to prepare their own Kenya top bar (KTB) from locally available material to conquer the high cost of investment and existing limitation of traditional beekeeping practice.

\subsubsection{Modern hives}

Modern beehive is the improved beehive technology of beekeeping practiced in the study area. The types of beehive used mostly determine the quantity and quality of hive products. Accordingly, the results of the study showed that, the application and adoption of movable-frame hive was very low as compared to traditional beehive with overall mean holdings of 2.18 with maximum 10 and minimum 1 hives per household. This is probably because of poor beekeeping extension services, high cost of investment and weak intervention on beekeeping by Government and non-government organizations in the study area. Accordingly, about $1.1 \%$ of model farmers were constructed modern hive from locally available materials' and practicing beekeeping. This indicated that beekeepers have an indigenous knowledge and initiation to incur their income as to improve their livelihood. Thus, providing strong extension services coupled with government and non-government intervention is crucial to encourage beekeepers to sustain beekeeping in the study area. According to information gathered from the beekeepers' currently, the costs of movable frame hive ranges from 1,000 to 1,200 Ethiopian birr which is not reasonably priced by small holder farmers. In addition, movable-frame hives consent to suitable colony management and use of a higher level technology with larger colonies, and can give higher yield and quality honey but are likely to require high cost of investment and trained man power [22].

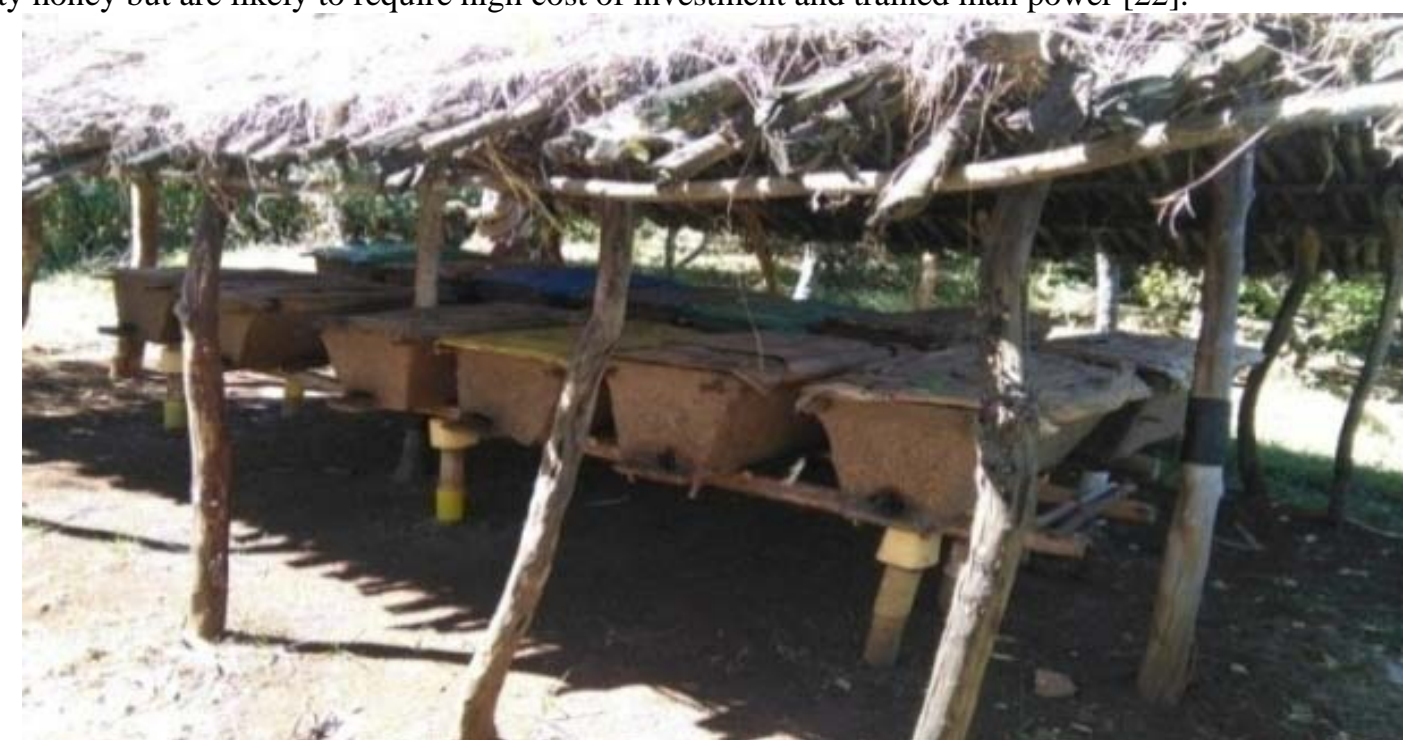

Figure 10. KTB made from local available materials at Horo.
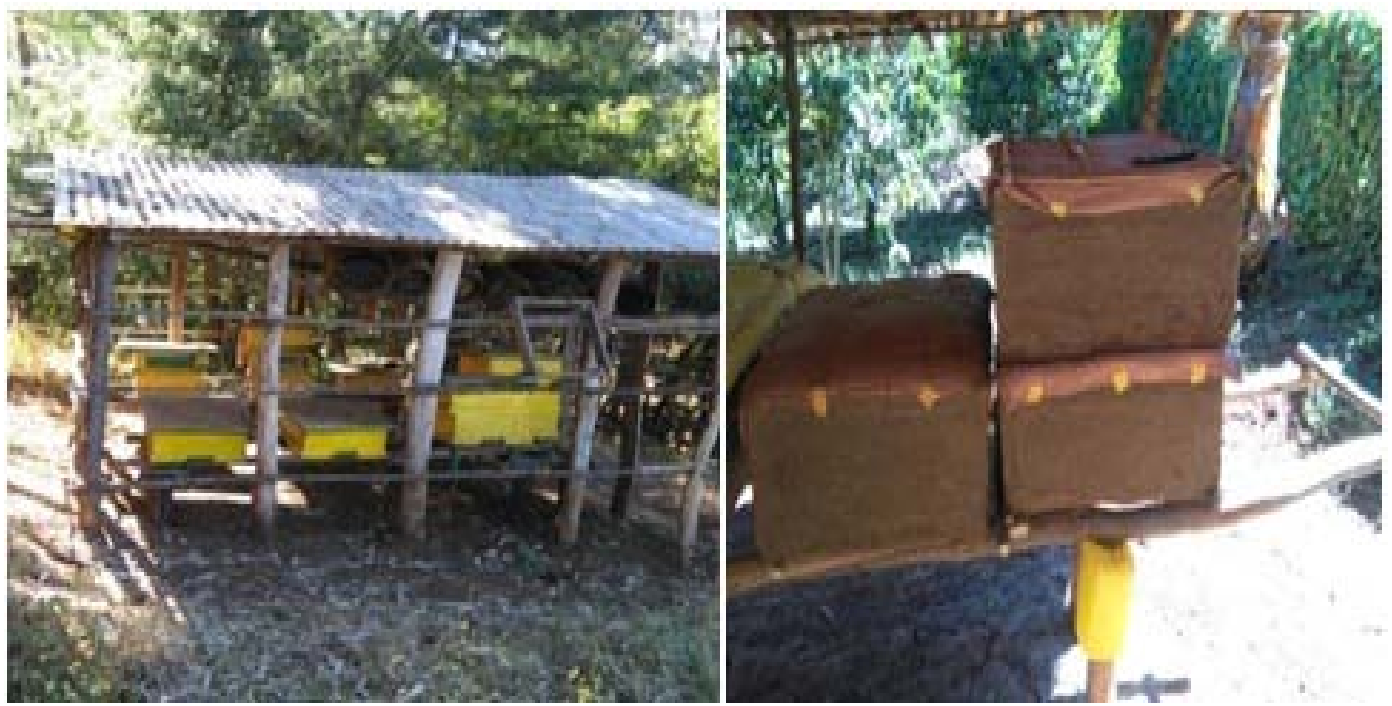

Figure 11. Movable frame hive made from timber on the left and locally available materials on the right at Horo. 


\subsubsection{Beekeeping trends in Horo}

As the study result showed, the majority (96.2\%) of the respondents follow traditional production system with only few beekeepers started using transitional (1.8\%) and movable-frame (2\%) beekeeping production system in the study area. Adoption of improved beehive technology is low probably due to poor extension services and high cost of investment. Similarly, [17] also reported about $98.26 \%, 0.3 \%$ and $1.36 \%$ of beekeepers follow traditional, transitional and Modern (moveable frame) production systems respectively in Bale Zone, Oromia region. Additionally, [23] also reported that related figures for the beekeepers in Adami Tullu, Jido Kombolcha in the mid rift valley of Ethiopia.

As the study result indicated about $68.5 \%$ of household beekeepers responded that the number of honeybee colony and their yields was declining overtime due to pesticide and herbicide application, pests, absconding, migration and lack of honeybee forage (Table 3). This finding agree with [17], [21], and [24] who reported pesticides and herbicides application, poor management, lack of improved beehives, shortage of bee forages, drought, lack of water and declining number of bee colonies as reasons for the products and honeybee population reduction. However, about $27 \%$ and $4.5 \%$ of respondents agree with increasing and stable way of production trends respectively. However, those respondents agree with increasing trend were due to having awareness of beekeeping production system, presence of good market price for bee products, availability of good honeybee flora, use of improved beekeeping technologies and good management of honeybees in the study area.

Table 3. Cause of decreasing trend of beekeeping in Horo

\begin{tabular}{|c|c|c|}
\hline \multicolumn{3}{|c|}{ Total Sample size $(\mathrm{N}=180)$} \\
\hline Cause of Decreasing trend & $\%$ & Rank \\
\hline Pesticide and herbicide application & 22.7 & $1^{\mathrm{st}}$ \\
\hline Pest & 16.6 & $2^{\text {nd }}$ \\
\hline Absconding & 15.5 & $3^{\text {rd }}$ \\
\hline Migration & 12.7 & $4^{\text {th }}$ \\
\hline Lack of bee forage & 10.5 & $5^{\text {th }}$ \\
\hline Drought & 8.2 & $6^{\text {th }}$ \\
\hline Bee Disease & 7.7 & $7^{\text {th }}$ \\
\hline Poor management (lack of attention) & 3.9 & $8^{\text {th }}$ \\
\hline Lack of credit & 2.2 & $9^{\text {th }}$ \\
\hline
\end{tabular}

Note: For each rank, the causes of absconding trend can be evaluated out of $100 \%$ by multiple response analysis.

\subsubsection{Characterization of honeybee's behaviours}

Beekeepers have their own skill and indigenous knowledge of characterizing honeybees specially the colour and stinging behaviour of the bees. As the study result, the household beekeepers categorize their honeybees as black (45.9\%), red (faki) (23.8\%) and mixture of black and red (30.3\%). Beekeepers in the study area characterized those bees with mixture of black and red as very aggressive in stinging behaviour and the red bees locally named "Faki" they believe that this type of honeybee is productive. Whereas, those bees black in colour is docile in behaviour and less productive as compared with red color bees. Furthermore, beekeepers behaviourally characterized their honeybee colonies based on their stinging behaviour as very aggressive (23.2\%), aggressive (49.7\%) and docile (27.1\%). As the study result indicated, this honeybee behavioural characterization result of the study area was similar with the honeybee races of A.M bandasi and A.M Scutellata. Similarly, this finding agree with [17] and [25] that they reported similarly for A.m bandassii the bee races that commonly found in sub moist central highland of Ethiopia and Apis Mellifera Scutellata in the west, south and southwest humid midlands.

\subsubsection{Incidence of absconding and migration}

According to the study result, migration of honeybee colonies incidence occurred March to May (35.6\%), September to November (22.8\%), December to February (20\%), June to August (19.4\%) and no response (2.2\%) (Figure 12). From these results of the study, the cause of migration of honeybees from March to May (35.5\%) might be due to the dearth period mostly drought and high temperature of the area. Besides to this, the migration of honeybee in the months of September to November (22.8\%) and December to February (20\%) was happened directly following the main honey flow season. Similarly this finding agree with [17], mainly migration honeybee colony occurred from March to May (43.3\%) might follow the dearth period mainly drought due to high temperature of the area in Bale Zone, Oromia region. Additionally, [23] reported that there was absconding and migration immediately following the main honey flow season and continued throughout the dry season (mainly from October-March) up to the next active period in Adami Tulu, Jido 
and Kombolcha districts in mid rift valley of Ethiopia.

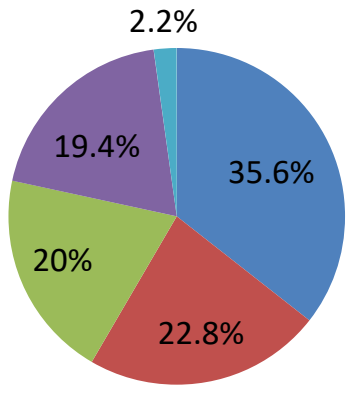

- March to May

- September - November

December- February

- June - August

- No response

Figure 12. Honeybee migration incidences in the study area.

On the other hand, as the study result showed that about $88.3 \%$ of beekeepers responded absconding of their honeybee colonies with the absconding frequency take place from March to May (38.8\%), followed by September to November (19.3\%), December to February (17.1\%), June to August (13.8\%) and no know how about absconding (10.5\%) (Figure 13).

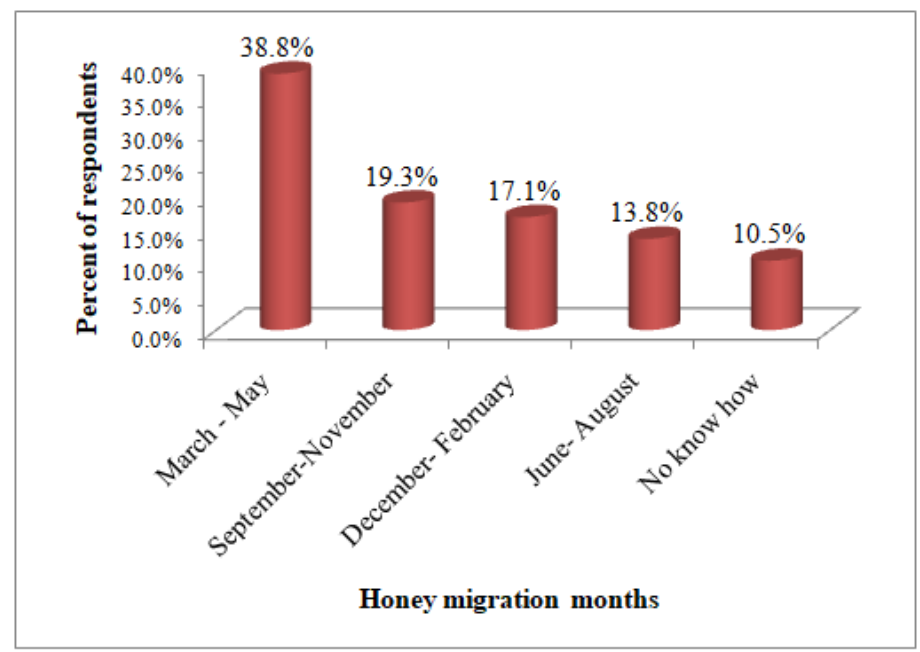

Figure 13. Honeybee absconding incidences in the study area.

As the study result revealed that the main reason of absconding of honeybee colonies in the study area was due to indiscriminate use of agro-chemicals (31.4\%), honeybee enemies (21\%), lack of bee forages (19.3\%), and poor management of beekeeping (13.3\%) (Table 4). In the study area, different mechanisms were used to overcome honeybee colonies absconding which include: cleaning and smoking the beehive, using bee enemies' protection mechanisms, providing supplementary feeds, queen clipping, leaving honey combs during harvesting and queen caging (locally made/purchased from market).

Table 4. Reasons of honeybee absconding in Horo district

\begin{tabular}{ccc}
\hline & Total Sample size (N=180) & Rank \\
\hline Reason of honeybee absconding & percentage & $1^{\text {st }}$ \\
\hline Indiscriminate use of agro-chemicals & 31.4 & $2^{\text {nd }}$ \\
Honeybee enemies & 21 & $3^{\text {rd }}$ \\
Lack of bee forages & 19.3 & $4^{\text {th }}$ \\
Lack of protection against bad weather & 16 & $5^{\text {th }}$ \\
\hline Poor management of beekeeping & 13.3 & \\
\hline
\end{tabular}

Note: For each rank, the causes of absconding trend can be evaluated out of $100 \%$ by multiple response analysis. 


\subsubsection{Honeybee colony swarming and swarm control}

As the study result showed that about $99.5 \%$ responded that the incidences of reproductive swarming of honeybee colony in their apiary while the remaining $0.5 \%$ had no awareness about swarming. As household beekeepers responded, the frequency of swarming were depends on the availability of honeybees flower and season of the swarming occurrences. About, $82.8 \%$ of the respondents had experience of catching honeybee colony swarm and the remaining $17.2 \%$ respondents had no swarm catching experience. As the study result indicated, majority of the respondents have an experience and indigenous knowledge of catching bee swarms in the study area. This result agrees with report of [21] who reported 85.80\% experience in catching swarm for beekeepers in Burie District of Amhara Region. Additionally, [17] also reported $84.4 \%$ of beekeepers in Bale Zone, Oromia Region practice catching swarm. On other hand about $77.8 \%$ of household beekeepers responded that swarm had merit to unite weak colony, replace non-productive colony and increase their number of colony. However the remaining $22.2 \%$ of beekeepers responded as swarming has no advantage. As the study showed that majority of the respondents (77.8\%) were controlling reproductive swarming by supering (those who had moveable frames), using large volume of hive, removing of queen cell, harvesting or cut combs, returning back to mother colony. This result implies that the household beekeepers have an experience of controlling honeybee swarms in the study area.

\subsubsection{Honeybee colonies inspection}

As the study result indicated, the household beekeepers inspect their honeybee colonies externally (87.8\%), internally (9.4\%) and not inspect (2.8\%) (Table 5). This indicates that majority of beekeepers of the study area inspect their beehives externally to check as the beehive was save from predator and ripeness of honey by honey odour and bee cluster of honeybees at the entrance. This might be due to the difficulty of the traditional hives for internal inspection mainly due to its placement (hanged on tall trees) and fixed combs attached to the body of traditional beehive. Similarly [26], [17], [23] and [18] reported that farmers in Ethiopia do not commonly practice internal hive inspection due to the difficulty of the traditional hives for internal inspection which is fixed combs attached to the body of traditional beehive.

Table 5. Hive inspection frequency in Horo district

\begin{tabular}{|c|c|c|c|c|}
\hline \multirow{3}{*}{ Frequency of inspection } & \multicolumn{3}{|c|}{ Total Sample size $(\mathrm{N}=180)$} & \\
\hline & \multicolumn{2}{|c|}{ Internal } & \multicolumn{2}{|c|}{ External } \\
\hline & Frequency & $\%$ & Frequency & $\%$ \\
\hline Every day & 4 & 2.2 & 9 & 5 \\
\hline Every three day & 3 & 1.7 & 11 & 6.1 \\
\hline Every week & 5 & 2.8 & 12 & 6.7 \\
\hline Every two week & 7 & 3.9 & 15 & 8.3 \\
\hline Every month & 8 & 4.4 & 20 & 11 \\
\hline If necessary & 39 & 21.5 & 44 & 24.4 \\
\hline Not at all & 114 & 63 & 69 & 38.3 \\
\hline Total & 180 & $100 \%$ & 180 & $100 \%$ \\
\hline
\end{tabular}

\subsubsection{Indigenous knowledge of beekeeping}

In the study area beekeepers have deep indigenous knowledge of traditional beekeeping. As the study result, the household beekeepers of the study area have an indigenous knowledge of constructing hives from locally available materials, plastering with mud, covering with grass, smoking baited hive with good attractant materials. Additionally, beekeepers have an experience of honey harvesting time by its odour, observing the clusters of honeybees at the entrance, hearing the buzzing sound and insert stick to beehive to check for honey presence. According to the study result, beekeepers have an experience to controlling reproductive swarming by removing brood, strengthening of colony by feeding like basso (powder of barely), identify plants utilized by bees, their flowering times, and poisonous plants to bees. In addition they use honey as local medicine, control of honeybee enemies by different means like cleaning around apiary and painting lubricant on hive stand, using ash, putting plastic on hive stand, using strings around the entrance of the apiary site for honey badger, identifying queens, swarm catching, identify quality of honey by viscosity, identifying adulterated honey by smelling, identifying quality honey by tasting and looking colour of honey. This indicated that the household beekeepers have good indigenous knowledge and experience of beekeeping in Horo district. This finding agrees with [17], [27] and [21] reported that beekeepers have deep indigenous knowledge of beekeeping practice. Furthermore, supporting indigenous knowledge of the beekeepers by scientific research has significant contributions to the 
beekeeping development and paramount importance to boost honey production and other hive products in Horo district in particular and the country in general.

\subsubsection{Honey yields from different beehives}

The amount of honey yield differ from hive to hive type and from one agro-ecology to another agro-ecology depending on different factors (like weather condition, the availability of flora, colony strength and management) exists. The study result revealed that the overall mean of honey yield harvested per hive per year in the study area during study time (November to mid-January) was $5.14 \mathrm{~kg}, 15 \mathrm{~kg}$ and $22.54 \mathrm{~kg}$ from traditional, transitional and moveable frame hives respectively (Table 6).

Table 6. Honey yields from different beehives at Horo district

\begin{tabular}{cc}
\hline Types of hives & Honey yield/hive/yrs. (mean in kg) \\
\hline Traditional hives & $5.14^{\mathrm{c}}$ \\
Transitional hive & $15^{\mathrm{b}}$ \\
Moveable frame hive & $22.54^{\mathrm{a}}$ \\
\hline
\end{tabular}

abc Means with different superscript letter are significantly different at $\mathrm{P}<0.05$.

As the study result revealed that there were high significant difference $(\mathrm{P}<0.05)$ between the three types of hives in terms of yield per hive per harvest and also between two agro-ecology of the study area. This was probably because of the fact that the variability of flora and whether condition differences exists between two agro-ecology of peasant associations, difference in colony strength, hive technology used and management practices of beekeepers. As the study result showed that the highest honey yields from traditional hive were recorded at the midland (6.01 \pm 0.41$)$ which might be relatively higher flora coupled with suitable environment could found in the midland. The lowest honey yield from traditional hive was recorded at highland $(4.26 \pm 0.15)$ (Table 7) which might be because of the most highland cold weather condition. From this study, it is realized that midland area is more favourable for beekeeping than highland areas. Similarly [20] reported that the average amount of honey harvested per traditional hive in West, South West and North Shewa zones to be $6.2 \mathrm{~kg}$. Additionally, [17] reported that the average amount of honey harvested per traditional hive in Bale zone, Oromia Region was $5.7 \mathrm{~kg}$.

Furthermore, the study result showed that, the lowest honey yield from transitional hive per harvest was recorded at highland (13.3 \pm 1.75$)$ agro-ecology (Table 7). This was probably because of the most highland cold weather condition and poor management practices of beekeepers. However, the highest honey yields were recorded at midland (16.76 \pm 1.98$)$ agro-ecology (Table 7). This might be because of suitable midland whether condition, good management practices of beekeepers and relatively higher flora could found in these peasant associations. From this study, it is concluded that midland area is more favourable for beekeeping than highland areas. However, the study result revealed that there is no significance difference ( $>0.05)$ in honey yields from modern hive at highland $(19.96 \pm 1.72)$ and midland (22.63 \pm 1.08$)$ (Table 7). This is probably due to good management practices (providing supplementary feed, frequent inspection, supering at right time). Generally, the honey yield from moveable frame hives at both agro-ecology were significantly different $(\mathrm{P}<0.05)$ from transitional and traditional hives. This is probably due to the existence of space for increasing performance of these beehives through good management practices coupled with favourable beekeeping environment. [28] Reported relatively lower value than the current result. That is the average amount of honey harvested per hive per year from transitional hive and modern hive were $10.83 \mathrm{~kg}$ and $15.2 \mathrm{~kg}$, respectively in Wonchi district of south west shoa zone. Similarly, [29] reported a comparatively higher value than the current finding. These authors reported that the average amount of honey harvested /hive/year from traditional and modern hive $20-25 \mathrm{~kg}$ and $45-50 \mathrm{~kg}$ respectively. These deviation in honey yield in different beehives and agro-ecologies might be attributed to variations in bee forages availability, weather conditions of an area, difference in management practices, used improved beehive technology and other factors.

Table 7. Honey yield (kg) obtained from different type of beehives per-harvest/hive/ year of the study area

Total Sample sizes $(\mathrm{N}=180)$

\begin{tabular}{|c|c|c|c|}
\hline \multirow{2}{*}{ Kebeles ( in agro-ecology) } & \multicolumn{3}{|c|}{ Types of beehives } \\
\hline & Traditional $($ Mean \pm SE) & Transitional $($ Mean \pm SE) & Moveable frame $($ Mean $\pm \mathrm{SE})$ \\
\hline Highland & $4.26 \pm 0.15^{\mathrm{Bc}}$ & $13.3 \pm 1.75^{\mathrm{Bb}}$ & $19.96 \pm 1.72^{\mathrm{Aa}}$ \\
\hline Midland & $6.01 \pm 0.41^{\mathrm{Ac}}$ & $16.76 \pm 1.98^{\mathrm{Ab}}$ & $22.63 \pm 1.08^{\mathrm{Aa}}$ \\
\hline
\end{tabular}

\footnotetext{
${ }^{\mathrm{AB}}$ Means across the column with different superscript letter are significantly different at $\mathrm{P}<0.05$ and ${ }^{\text {abc }}$ Means across the row with different superscript letters are significantly different at $\mathrm{P}<0.05, \mathrm{SE}=$ Standard Error, $\mathrm{N}=$ Number of respondents.
} 


\subsubsection{Smoking materials and its effect on honey quality}

The study result showed that there was different smoking materials were used in order of their importance and availability in locality for controlling honeybees whenever inspecting the colony and harvesting honey. As the study result revealed that, the common smoking materials used during honey harvesting and inspection in the study area were Ekebergia capensi (somboo) (49.4\%), Olea europaea (ejersa) (22.2\%), cow dung (dike) (16.7\%), karabicho (6.10\%), beeswax (5\%) and Gari (0.6\%) (Table 8). Similarly, [30] reported that beekeepers use smoking materials during harvesting of honey and inspection like Teff straw, Vernonia amegdalina leaves and animal dung to manage and drive away the bees. Additionally, [17] reported that the major smoking material in order of its importance in their locality were Bark of Juniperus procera, Old cloth and Hasufe ranked as first and second and third respectively. However, as a study result indicated, majority about $60.7 \%$ of household beekeepers replied the smoke had negative effects on quality of honey if not used properly. This finding showed that, improper (over smoking) using of smoking had negatively affects colour (22.3\%), odour (15.5\%), tastes (15.5\%), and make poison (12.3\%) (Table 8). As the study result revealed that about $36 \%, 47.5 \%$ and 16.5 of the respondents use light smoking, appropriate smoking and too much smoking (Table 8).

\subsubsection{Attractant materials used in the study area}

As the study result showed that attractant materials were used to attract swarms to the new hive and to kill micro-organisms found in hive. In the study area, beekeepers had good indigenous knowledge about the attractant materials that attract swarming to new hive and kill micro-organisms found in hive separately. As the study result revealed that the most common attractant materials used were barks, leaves, roots and stem of selected trees, crude beeswax (gaga), gum (hitana) and body soap and perfume (shito) (Table 9). Majority about $98.9 \%$ of beekeepers used these attractant/fumigant materials for baited hive to attract swarms and kill micro-organisms, Beekeepers believed that smoking with attractant materials could attract swarms to new hives and smoking with like Ekebergia capensi (somboo) and Olea europaea (ejersa) could initiate to prepare honeybees to start brood rearing and for other hive duties especially during active flowering seasons in the study area. Selecting and using of appropriate attractant materials were important to attract the bees to new hive, initiate to carry out their hive duties and control micro-organisms. Similarly, [2] reported that pollen production by Olea europaea is valuable for strengthening colonies and stimulating brood rearing.

Table 8. Common smoking materials and its effect on honey quality in Horo

\begin{tabular}{|c|c|c|c|c|}
\hline \multicolumn{5}{|c|}{ Total Sample size $(\mathrm{N}=180)$} \\
\hline Smoking Materials & $\%$ & rank & smoking effect & $\%$ \\
\hline Ekebergia capensi (somboo) & 49.4 & $1^{\text {st }}$ & Color & 22.30 \\
\hline Olea europaea (ejersa) & 22.2 & $2^{\text {nd }}$ & Odour & 15.10 \\
\hline Cow dung (dike) & 16.7 & $3^{\text {rd }}$ & Tastes & 15.10 \\
\hline Karabicho & 6.10 & $4^{\text {th }}$ & Make poison & 12.30 \\
\hline Beeswax (gaga) & 5.0 & $5^{\text {th }}$ & No effect & 35.20 \\
\hline Gari & 0.6 & $6^{\text {th }}$ & - & - \\
\hline Overall & 100 & & & 100 \\
\hline
\end{tabular}

Note: For each rank, the common smoking material can be evaluated out of $100 \%$ by multiple response analysis.

Table 9. Attractant materials identified in Horo

\begin{tabular}{ccccc}
\hline SN & Local Name & Scientific Name & Plant part used & Method of application \\
\hline 1 & Somboo & Ekebergia Capensis & Bark & Smoking \\
2 & Ejersa & Olea Europacea & Leaf/Muka & Smoking \\
3 & Waddeessa & Cordial Africana & Bark & Smoking \\
4 & Heexoo & Hagenia abyssinica & Hoffaa & Smoking \\
5 & Kusaayee & Lippia adoensis & leaf & Plastering \\
6 & Gatamaa & Schefflera Abyssinica & Bark & Smoking \\
7 & Baddeessaa & Syzygiumguineense & Bark & Smoking \\
8 & Gagaa & Beeswax & Crude & Smoking \\
\hline
\end{tabular}




\begin{tabular}{ccccc}
\hline 9 & Qayya & Warburgia ugandensis & Muka & Smoking \\
10 & Waatoo & Osyris Quadripartita & Muka & Smoking \\
11 & Shittoo & Perfume & As it is & Spraying \\
12 & Saamunaa qaamaa & Body soap & Solution/As it is & Smoking/spraying \\
13 & Cilaattamoo & Ruta chalepensis & Leaf & Plastering \\
14 & Ixaana & Commiphora myrrha & As it is & Smoking \\
15 & Dinbilaala & Not identified & Leaf & Smoking \\
16 & Xoosinyii & Sature japuncutata & Leaf & Smoking \\
\hline
\end{tabular}

\section{Conclusion}

In Horo Beekeeping practices is an earliest farming activity which was practiced side line with other farm activities. The area has high potential for beekeeping and in the area three types of beekeeping production systems were practiced. The survey result indicated that majority of the beekeepers engaged in beekeeping were productive age and have deep indigenous knowledge of traditional production system. According to finding of this study, it concluded that beekeeping in the study area is predominantly practiced by and defined as a men's job with only few women beekeepers involved. In Horo, three beekeeping production systems were identified, with traditional beekeeping dominating up to $96.2 \%$ being practiced (near homestead and under the eaves of the house) with transitional and moveable frame beehives beekeeping accounting $2 \%$ and $1.8 \%$ of the production systems respectively. However, traditional production system has significantly contributed to low productivity and inconsistent quality of honey. As a result, beekeepers were not benefited from this sub-sector. Thus, to benefit the large smallholder beekeepers, it is important to merge their indigenous knowledge with scientific approach.

\section{References}

[1] Desalegn, B. (2014). Assessment of Pesticides Use and its Economic Impact on the Apiculture Subsector in Selected Districts of Amhara Region, Ethiopia.

[2] Fichtl, R. and Admasu, A. (1994). Honeybee Flora of Ethiopia. Margraf Verlag, Germany. (FAO) Food and Agriculture Organization, 1996. Value added products from beekeeping (FAO Agricultural Services Bulletin No. 124). Rome, Italy.

[3] Gemechis, L. (2014). Review of progress in Ethiopian honey production and marketing. Holeta Bee Research Center (HBRC), Holeta. P.O. Box 22 Ethiopia.

[4] Nuru, A. (2007). Atlas of pollen grains of major honeybee flora of Ethiopia. Holeta Bee Research Centre. Commercial Printing Enterprise. Addis Ababa, Ethiopia. P. 152.

[5] CSA (Central Statistical Agency), 2017/18. Agricultural sample survey 2017/2018, volume II. Report on Livestock and Livestock characteristics. Addis Ababa. Statistical Bulletin, P. 570.

[6] MoARD (Ministry of Agriculture and Rural Development). (2016). The third residue monitoring plan for honey from Ethiopia. Produced by members of the Ethiopian Honey and Beeswax Producers and Exporters Association (EHBPEA). Addis Ababa Ethiopia.

[7] Gizachew, S. (2011). Women Economic Leadership through Honey Value chain Development in Ethiopia. Paper presented on Workshop on Gender \& Market Oriented Agriculture $1^{\text {st }}$ February 2011, Addis Ababa, Ethiopia.

[8] Sebsib, A. (2018). Beekeeping Practice, Opportunities, Marketing and Challenges in Ethiopia: Review. Dairy and Vet Sci J., 2018, 5(3): 555662. DOI: 10.19080/JDVS.2018.05.555662.

[9] Bekele, T., Desalegn, B., and Mitiku, E. (2017). Beekeeping practices, trends and constraints in Bale, South-eastern Ethiopia.

[10] IVCA (Integrated Value Chain Analyses) (2009). Integrated Value Chain Analyses for Honey and Beeswax Production and Marketing in Ethiopia and Prospects for Exports. The Netherlands Development Organization (SNV). Pp. 9-10.

[11] Nuru, A. (1999). Quality state and grading of Ethiopian honey. Pp. 74-82. Proceedings of the first National Conference of Ethiopian Beekeepers Association (EBA), June 7-8, 1999, Addis Ababa, Ethiopia.

[12] Mulgeta, D. (2014). Horo Woreda Honey and other Bee products Value chain analysis.

[13] Woreda Agricultural Office 2012. Basic datas of the district.

[14] Hartmann, I. (2004). The management of resources and marginalization in beekeeping Societies of South West Ethiopia. Paper submitted to the conference: Bridge Scales and Epistemologies, Alexandria. P. 1. 
[15] Workneh, A. (2006). Identification and documentation of indigenous knowledge of beekeeping practice. Proceedings of the 14th Ethiopian Society of Animal Production, ESAP. Addis Ababa.

[16] Bekele, T. (2006). Beekeeping practices, factors affecting production, quality of honey and beeswax in Bale Zone, Oromia Region. M.Sc. Thesis.

[17] Chala, K. (2010). Honey Production, Marketing System and Quality Assessment in Gomma Woreda, South Western Ethiopia.

[18] Gichora, M. (2003). Towards Realization of Kenya’s Full Beekeeping Potential: A Case Study of Baringo district. Ecology and Development series No.6 2003. CuvillierVerlag Gottingen, Gottingen, Germany. P. 157.

[19] Workneh, A. (2006). Identification and documentation of indigenous knowledge of beekeeping practice. Proceedings of the 14th Ethiopian Society of Animal Production, ESAP. Addis Ababa.

[20] Tessega, B. (2009). Honeybee Production and Marketing Systems, Constraints and opportunities in Burie District of Amhara Region, Ethiopia. A Thesis Submitted to the Department of Animal Science and Technology, School of Graduate Studies Bahirdar University.

[21] Crane, E. (1990). Bees and Beekeeping: Science, Practice and World Resources. Comstock Publishing Associates (Cornell University Press), Ithaca, New York.

[22] Tesfaye, K. and Tesfaye, L. (2007). Study of honey production systems in Adami Tulu Jido Kombolcha district in mid rift valley of Ethiopia. Livestock Research for Rural Development. Volume 19, Article \# 11.

[23] Haftu, K. and Gezu, T. (2014). Survey on honey production systems, challenges and opportunities in selected areas of Hadya Zone, Ethiopia.

[24] Amssalu, B., Nuru, A., Sarah, E., Radloff, H., Randall, H. (2004). Multivariate morphometric analysis of Honeybees (Apis mellifera L.) in the Ethiopian region. Apidologie, 35(2004): 71-84.

[25] Kerealem, E. (2005). Honeybee Production Systems, Opportunities and Challenges in Enebse Sar Midir Wereda (Amhara Region) and Amaro Special Woreda (Southern Nations, Nationalities and Peoples Region), Ethiopia. M.Sc. Thesis.

[26] Solomon, B. (2009). Indigenous knowledge and its relevance for sustainable beekeeping development: A case study in the Highlands of Southeast Ethiopia Department of Animal Sciences, Mada Walabu University, PO Box 84, Bale Robe, Ethiopia.

[27] Taye, B. and Marco, V. (2014). Assessment of constraints and opportunities of honey production in Wonchi District South West Shewa Zone of Oromia, Ethiopia. American Journal of Research Communication, 2(10): 342-353. www.usa-journals. com, ISSN: 2325-4076.

[28] Gidey, Y. and Mekonen, T. (2012). Participatory Technology and Constraints Assessment to Improve the Livelihood of Beekeepers in Tigray Region, northern Ethiopia. Momona Ethiopia journal of Science, Vol.2, No.1.

[29] Shenkute, A. G., Getachew, Y., Assefa, D., Adgaba, N., Ganga, G., and Abebe, W. (2012). Honey production systems (Apis mellifera L.) in Kaffa, Sheka and Bench-Maji zones of Ethiopia. Journal of Agricultural Extension and Rural Development, 4(19), 528-541. 